\title{
Nutritional status of children under five in three State foster care institutions in Sri Lanka
}

\section{Channa R Jayasekera ${ }^{1}$}

(Index words: Protein-energy malnutrition)

\begin{abstract}
This study evaluated the prevalence of protein energy malnutrition (PEM) in children under five years $(n=52)$, in three randomly selected, State operated foster care institutions in Sri Lanka. The prevalence of PEM, was (51.9\%), underweight $(63.5 \%)$ and wasting $(25.0 \%)$ was found to be considerably higher than the national prevalence $(13.5 \%$, $29.4 \%, 14.0 \%$, respectively). Based on this preliminary evidence, it is recommended that a study representative of all institutionalised children in both State and private facilities be conducted to identify deficiencies and recommend improvements to institutional care in Sri Lanka.
\end{abstract}

\section{Introduction}

Foster care institutions in the developing world function importantly in protecting and caring for children who are orphaned, abandoned, abused, or placed under State probation. In Sri Lanka, their importance in social welfare was highlighted in the aftermath of the tsunami disaster that left orphaned or destitute an estimated 1000 children [1]. The Sri Lankan Department of Probation and Child Care Services operates eight State Receiving Homes, which act as transit centres for children until adoption or adulthood. A 1998 report of the Department states that 297 children were housed in these locations, which are mandated to provide appropriate nutrition, health care access, clothing, schooling access, and other basic requirements [2]. The Department also serves as the regulatory body for many more voluntary (private) foster care institutions in the country.

A nutritional evaluation of institutionalised children in Sri Lanka has not been reported in the literature. This study, conducted in early 2004, examined the nutritional status of children under five in three of the eight State Receiving Homes in Sri Lanka. It presents data on the general, sex-specific, institution-specific, birthweight-specific, and duration-specific prevalence of stunting, underweight and wasting. The study is not representative of all institutionalised children in Sri Lanka since it does not include five State Receiving Homes and voluntary institutions.

\section{Materials and methods}

Prajapathi Children's Home in Panadura, Tikiri Sevana Children's Home in Peradeniya, and Ruhunu Children's
Home in Galle were randomly selected from among eight State Receiving Homes. Informed consent for the study was obtained in writing from the Commissioner of the Department of Probation and Child Care Services, respective Provincial Commissioners of the Department, and from matrons of each institution before evaluating children. The combined occupancy of the three institutions was 103 children of all ages ( $n=21,36,46$, respectively). Children were recruited if they possessed a government issued birth certificate or Child Health and Development Record (CHDR), and were between 3 and 60 months of age, and not physically disabled. Of the 103 children, 77 were under five, of whom $52(n=12,13,27$, respectively) satisfied the other selection criteria and were recruited.

Recruited children were weighed on a UNICEF electronic scale with $100 \mathrm{~g}$ accuracy. Recumbent length for those $<24$ months, and height for those $>25$ months was measured for each child by two individuals using a standard technique, with a UNICEF height board with $0.1 \mathrm{~cm}$ accuracy [3]. Besides anthropometric data, age, and sex, data on date of admission, and birth weight from the CHDR if available, were collected. The duration of parental care and breastfeeding could not be recorded due to unreliable family histories.

Anthropometric analyses, viz., length- or height-forage, weight-for-age, and weight-for-height Z-scores were performed with EpiInfo v.3.2.2, based on the 1978 NCHS/WHO growth reference [4]. Determining the degree of stunting, underweight and wasting followed the WHO classification, where $\leq 2$ to -3 Z-scores was considered moderate, and $\leq 3 \mathrm{Z}$-scores was considered severe for each indicator. Stratified analysis was performed to determine prevalence by age group, sex, birthweight (low or appropriate birthweight), and duration of institutionalisation. Additionally, matrons were administered a questionnaire to determine the number of care givers, nutrition provided to infants under two years, health care and nutritional monitoring, access to formal education, and frequency of inspection visits from the Department of Probation and Child Care Services.

\section{Results}

Recruited children ranged from 3.9 to 57.3 months of age $($ median $=18$, mean $=23.6, \mathrm{SD}=17.3)$. Period of

${ }^{1}$ Duke University Medical Centre, 544 Finley St, Durham, NC 27705, USA.

Correspondence: CRJ, e-mail: <channa.jayasekara@duke.edu> (Competing interests: none declared). Received 14 May 2005 and revised version accepted 21 November 2005. 
Table 1. Prevalence $(n=52)$ of moderate and severe stunting, underweight and wasting. Degree of malnutrition is considered moderate if Z-score is $\leq-2$ and severe if Z-score is $\leq-3$ of the 1978 NCHS/WHO Reference

\begin{tabular}{lccc}
\hline & $\begin{array}{c}\text { Total } \\
(\%)(n)\end{array}$ & $\begin{array}{c}\text { Moderate } \\
(\%)(n)\end{array}$ & $\begin{array}{c}\text { Severe } \\
(\%)(n)\end{array}$ \\
\hline Stunting & $51.9(27)$ & $34.6(18)$ & $17.3(9)$ \\
Underweight & $63.5(33)$ & $40.4(21)$ & $23.1(12)$ \\
Wasting & $25.0(13)$ & $25.0(13)$ & $0.0(0)$ \\
\hline
\end{tabular}

Table 2. Prevalence of stunting, underweight and wasting vis-à-vis characteristics of study population. Stunting, underweight and wasting are defined by Z-scores $\leq-2$ of the 1978 NCHS/WHO Reference

\begin{tabular}{|c|c|c|c|}
\hline Group & $\begin{array}{l}\text { Stunting } \\
(\%)(n)\end{array}$ & $\begin{array}{l}\text { Underweight } \\
\quad(\%)(n)\end{array}$ & $\begin{array}{l}\text { Wasting } \\
(\%)(n)\end{array}$ \\
\hline \multicolumn{4}{|l|}{ Age (n) } \\
\hline 3-24 months (29) & $48.3(14)$ & $51.7(15)$ & $17.2(5)$ \\
\hline 25-59 months (23) & $56.5(13)$ & $78.3(18)$ & $34.8(8)$ \\
\hline \multicolumn{4}{|l|}{$\operatorname{Sex}(n)$} \\
\hline Female (23) & $43.5(10)$ & $47.8(11)$ & $21.7(5)$ \\
\hline Male (29) & $58.6(17)$ & $75.9(22)$ & $27.6(8)$ \\
\hline \multicolumn{4}{|l|}{ Birthweight (n) } \\
\hline $\begin{array}{l}\text { Low birthweight } \\
\text { (21) }\end{array}$ & $81.0(17)$ & $76.2(16)$ & $28.6(6)$ \\
\hline $\begin{array}{l}\text { Appropriate } \\
\text { birthweight (20) }\end{array}$ & $40.0(8)$ & $50.0(10)$ & $25.0(5)$ \\
\hline \multicolumn{4}{|l|}{ Duration } \\
\hline \multicolumn{4}{|l|}{ Institutionalised (n) } \\
\hline$\leq 12$ months $(31)$ & $41.9(13)$ & $48.4(15)$ & $22.6(7)$ \\
\hline >12 months (21) & $66.7(14)$ & $85.7(18)$ & $28.6(6)$ \\
\hline \multicolumn{4}{|l|}{ Institution (n) } \\
\hline $\begin{array}{l}\text { Prajapathi children's } \\
\text { home (12) }\end{array}$ & $58.3(7)$ & $83.3(12)$ & $25.0(3)$ \\
\hline $\begin{array}{l}\text { Tikiri Sevana } \\
\text { children's }\end{array}$ & & & \\
\hline home (13) & $30.8(4)$ & $23.1(3)$ & $15.4(2)$ \\
\hline $\begin{array}{l}\text { Ruhunu children's } \\
\text { home ( } 27)\end{array}$ & $59.3(16)$ & $74.1(20)$ & $29.6(8)$ \\
\hline
\end{tabular}

institutionalisation ranged from 0.1 to 56.1 months (mean $=14.6, \mathrm{SD}=13.8$ ). Of the recruited children, $44.2 \%$ (23) were female. The general prevalence of PEM is shown in Table 1, and Table 2 shows prevalence when stratified. The prevalence of these indicators in institutionalised children is above the respective national prevalence, as shown in Table 3. Further, children institutionalised for over 12 months were worse off (stunted $=66.7 \%$, underweight $=$ $85.7 \%$, wasted $=28.6 \%$ ) than those institutionalised for 12 months or less (stunted $=41.9 \%$, underweight $=48.4 \%$, wasted $=22.6 \%$ ). (Table 2) Birthweight information was available for $78.8 \%(n=41)$ of children, of whom 21 had low birthweight (LBW) $(<2500 \mathrm{~g})$ and 20 had appropriate birthweight. Gestational age, including incidence of preterm birth, could not be determined reliably.

The children:care giver ratio of the institutions was 5:1 on average (3.5:1 at Prajapathi, 5:1 at Tikiri Sevana,
Table 3. The prevalence of stunting, underweight and wasting in the study population compared with the National prevalence as provided in the Demographic and Health Survey 2000 [11]

\begin{tabular}{lcc}
\hline & $\begin{array}{c}\text { Prevalence in studied } \\
\text { institutions (\%) }\end{array}$ & $\begin{array}{c}\text { National prevalence } \\
(\%)\end{array}$ \\
\hline Stunting & 51.9 & 13.5 \\
Underweight & 63.5 & 29.4 \\
Wasting & 25.0 & 14.0 \\
\hline
\end{tabular}

6.5:1 at Ruhunu), based on information reported by matrons. At all three institutions, matrons reported the on-demand provision of Nestlé Lactogen 1 formula for infants under 6 months and Nestlé Lactogen 2 formula for those 6-24 months. Pre-school facilities were not provided at Prajapathi, though both Tikiri Sevana and Ruhunu did have such facilities. Only children at Tikiri Sevana had regular health and nutritional monitoring, performed by an a physician. At Prajapathi and Ruhunu, contact with health care providers was limited to when children presented with symptoms warranting a clinic visit. Frequency of inspections by the Department of Probation and Child Care Services was reported as being weekly at Ruhuna, monthly at Tikiri Sevana, and biannual at Prajapathi.

\section{Discussion}

The growth and development of institutionalised children is lower than the attainments of their mothered peers in household environments, largely due to the lower quality of care, lack of primary attachment figures (parents, guardian) and often, traumatic histories of the children $[5,6,7,8]$. Gestational and peri/neonatal factors can also be contributory, given that the social contexts that lead these children to institutionalisation often imply extreme poverty, unwanted pregnancy and so on. Hence, foster care institutions, already resource limited, are often challenged with optimising growth and development of already biologically and psychosocially deprived children.

Low birthweight, most likely due to intrauterine growth retardation (IUGR), is a potent contributor to suboptimal growth [9]. Among the children with known birthweights, $51.2 \%$ (47.4\% of females, $55.6 \%$ of males) had LBW, while the National prevalence is $17 \%$ [10]. IUGR infants have been shown to never completely catch up to the growth trajectories of their non-IUGR peers, especially in non-conducive postnatal environments. It was found in my study that stunting prevalence was $81 \%$ in children with LBW, compared to $40 \%$ in those with appropriate birthweight (Table 2) [11]. The non-conduciveness of these institutional environments is evidenced by the finding that acute PEM (wasting) was prevalent in $28.6 \%$ of children who had been institutionalised for over 12 months (Table 2). This finding that children continue to be acutely malnourished during institutionalisation strongly implicates the institutional environment. 
Though inadequately studied here, care provision is an exceptionally important consideration when evaluating foster care institutions. Care is considered an underlying determinant of child malnutrition, on par with food insecurity and poor health services or unhealthy environment $[12,13]$. It is also one of the most subjectively palpable deficiencies of institutions. Institutional care has been implicated extensively in studies that demonstrate growth and development improvements of children when transferred to adoptive homes [14,15]. However, institutionalisation does not necessarily preclude provision of optimal care, provided adequate numbers of care givers and emphases on comprehensive care and emotional attachment.

Despite the obstacles faced by children in such institutions, a number of strategies to at least partially ameliorate sub-par growth and development have been demonstrated. For example, it has been shown that reversing IUGR-mediated stunting is most efficacious if relevant interventions are initiated before children are 24 months of age [16]. For all children, providing the best possible nutritional, health, psychological and social environment is paramount. Environmental interventions include improving nutritional quality, emphasis on care via structured play and physical activity, frequent and effective social, emotional, and cognitive interactions between children and caregivers, regular health/nutritional monitoring, and provision of formal education [6,7,17]. The institutions studied here did not demonstrate systematic and uniform incorporation of such vital environmental factors into the institutional atmosphere.

This study shows the urgency to improve the nutritional status of children in the studied foster care institutions. Given that these nutritional characteristics are likely reflected in children in other foster care institutions in Sri Lanka, a nationally representative survey of the prevalence of nutritional deficiencies, together with evaluation of psychological development and quality of care in institutions should be conducted. The provision of State sponsored and State regulated institutional care to abused, vulnerable, and at-risk children is invaluable, especially in the aftermath of the tsunami disaster which left an estimated 1000 children in destitution [1]. Providing such children a foothold to productive adulthoods through a relatively optimal childhood should be an overarching goal of such care, especially when institutions are not merely 'transit shelters', but medium-to-long term homes. The generation of a wholesome environment encompassing appropriate nutrition, care, access to health services and basic education, is critical to maximising the human capital of these children.

\section{Acknowledgements}

I thank Mr. D Liyanarachchi of the Nutrition Coordination Division, Ministry of Health, for assistance in measurement of subjects, and the United Nations World Food Programme-Sri Lanka, for permitting the use of their equipment.

\section{References}

1. UNICEF. Caring for Sri Lankan children who have lost parents. United Nations Children's Fund, New York, 2005.

2. UNHCHR. Second periodic report of Sri Lanka to the United Nations Committee on the Rights of the Child. United Nations High Commissioner for Human Rights, Geneva, 2002.

3. Cogill B. Anthropometric indicators measurement guide. Food and Nutrition Technical Assistance Project, Washington DC, 2001.

4. Epilnfo v. 3.2.2, Centers for Disease Control and prevention, USA, 2004.

5. Otieno PA, Nduati RW, Musoke RN, Wasunna AO Growth and development of abandoned babies in institutional care in Nairobi. East African Medical Journal 1999; 76: 430-5.

6. Mitchell HS, Santo S. Nutritional improvement in Hokkaido orphanage children-1960-1970. Journal of the American Dietetic Association 1978; 72: 506-9.

7. Miller PM, Gorski PA, Borchers DA, Jensita JA, Johnson $\mathrm{CD}$, Kaufman ND et al. Developmental issues of young children in foster care. Pediatrics 2000; 106: 1145-50.

8. Sigal JJ, Perry JC, Rossignol M, Ouimet MC. Unwanted infants: psychological and physical consequences of inadequate orphanage care 50 years later. American Journal of Orthpsychiatry 2003; 73: 3-12.

9. Kramer MS. Intrauterine growth and gestational duration determinants. Pediatrics 1987; 80: 502-11.

10. Demographic and Health Survey. Sri Lanka Department of Census and Statistics, Colombo, 2000.

11. Martorell R, Ramakrishnan U, Schroeder DG, Melgar P, Neufeld L. IUGR, body size, body composition, and physical performance in adolescence. European Journal of Clinical Nutrition 1998; 52(Suppl): 543-53.

12. UNICEF. Strategy for improved Nutrition of Children and Women in developing countries. United Nations Children's Fund, New York, 1990.

13. Stephenson LS, Latham MC, Ottesen EA. Global malnutrition. Parasitology 2000; 121: S5-S22.

14. Engle PL, Lhotska L. The role of care in programmatic actions for nutrition: Designing programmes involving care. Food and Nutrition Bulletin 1999; 20:121-35.

15. Morison SJ, Ames EW, Chishold K. The development of children adopted from Romanian orphanages. MerrillPalmer Quarterly 1995; 41: 411-30.

16. Martorell R, Khan LK, Schroeder DG. Reversibility of stunting: epidemiological findings in children from developing countries. European Journal of Clinical Nutrition 1994; 48: S45-S57.

17. Taneja V, Sriram S, Beri RS, Sreenivas V, Aggarwal R, et al. Not by bread alone: impact of a structured 90-minute play session on development of children in an orphanage. Child: Care, Health and Development 2002; 28: 95-100. 